\title{
PENGARUH KOMUNIKASI PERSUASIF DALAM MENINGKATKAN KESADARAN SOLIDARITAS ANGGOTA SCOOTER MODS BOGOR INDONESIA
}

\section{THE IMPACT OF COMMUNICATIONS TO ACQUIRE SOLIDARITY AWARENESS OF SCOOTERS MODS BOGOR INDONESIA}

\author{
NA Pradipto1a, Sukarelawati², AA Kusumadinata ${ }^{3}$ \\ 1,2,3 Jurusan Ilmu Komunikasi, Fakultas Ilmu Sosial dan Ilmu Politik, Universitas \\ Djuanda \\ Jl. Tol Ciawi No.1 Kotak Pos 35 Bogor 16720. \\ 1aEmail Korespondensi : novanda.agung19@gmail.com
}

(Diterima: 10-04-2017; Ditelaah: 20-8-2017; Disetujui: 27-08-2017)

\begin{abstract}
This study obstained to find out how persuasive communication in achieving awareness and solidarity, and whether there is influence between persuasive communication to the solidarity of Scooter Mods Bogor Indonesia members achieve the goal. The research method used in this research was descriptive and associative research methods, namely research that was processed and analyzed to be taken conclusion. The result of research showed that persuasive communication was on score 4.33 which means it was in classification of Very Good and for solidarity was at 4.52 which means was in the classification Very Good, while the correlation value between persuasive communication variables with solidarity was equal to 0.646 . If based on interpretation coefficient included in the category Strong. Solidarity was influenced by persuasive communication $41.73 \%$, and $58.27 \%$ by other factors not examined by the author.
\end{abstract}

Keywords : solidarity, scooter, persuasive communication

\begin{abstract}
ABSTRAK
Penelitian ini bertujuan untuk mengetahui bagaimana komunikasi persuasif dalam mencapai kesadaran serta solidaritas, dan apakah ada pengaruh antar komunikasi persuasif terhadap solidaritas anggota Scooter Mods Bogor Indonesia mecapai tujuan. Metode penelitian yang digunakan dalam penelitian ini adalah metode penelitian deskriptif dan asosiatif, yaitu penelitian yang diolah dan dianalisis untuk diambil kesimpulan. Hasil penelitian menunjukan bahwa komunikasi persuasif berada pada skor 4,33 yang artinya berada pada klasifiaksi penilaian Sangat Baik dan untuk solidaritas berada pada skor 4,52 yang artinya berada pada klasifikasi Sangat Baik, sedangkan nilai korelasi antara variable komunikasi persuasif dengan solidaritas adalah sebesar 0,646. Jika berdasarkan interpretasi koefisien termasuk dalam kategori Kuat. Solidaritas dipengaruhi oleh komunikasi persuasif sebesar $41,73 \%$, dan $58,27 \%$ oleh faktor lain yang tidak diteliti oleh penulis.
\end{abstract}

Kata Kunci : Solidaritas, scooter, Komunikasi Persuasif

NA Pradipto, Sukarelawati, AA Kusumadinata. 2017. Pengaruh Komunikasi Persuasif dalam Meningkatkan Kesadaran Solidaritas Anggota Scooter Mods Bogor Indonesia. Jurnal Komunikatio 3(2): 61-68. 


\section{PENDAHULUAN}

Komunitas merupakan suatu kelompok sosial yang memiliki habitat lingkungan dan ketertarikan yang sama terhadap sesuatu hal dalam ruang lingkup kepercayaan atau yang lainnya (Wenger et.al 2002). Komunitas terlahir karena kuatnya rasa kesamaan, baik dalam gaya ataupun selera terhadap sesuatu hal, salah satunya adalah komunitas motor. Komunitas motor sebetulnya sudah ada sejak tahun 1948, antara lain Hell's Angel merupakan komunitas motor pertama yang terbentuk di California, Amerika Serikat. Komunitas ini terdiri dari orang-orang yang mengendarai Harley Davidson dan memiliki ciri yang khusus yaitu mereka merupakan kaum dari golongan kelas atas. Kelompok tersebut memotivasi terbentuknya komunitas motor lainnya yaitu Mod. Para kaum Mod umumnya adalah anak muda pekerja yang ingin seperti komunitas golongan atas dengan ciri yang nyentrik dan mengenakan atribut khasnya yaitu Jaket Parka. Vespa merupakan kendaraan utama komunitas Mod.

Fenomena komunitas motor di atas tidak luput dari penilaian sebagaian masyarakat yang terkesan negatif. Komunitas motor seolah-olah disamakan dengan geng-geng motor yang suka melakukan anarkis. Supaya komunitas motor tersebut menghilangkan pandangan negatif yang melekat padanya, maka mereka membuktikan eksisnya dengan mengadakan acara yang bersifat sosial, sehingga diharapakan menumbuhkan rasa solidaritas yang tinggi diantara anggotanya.

Salah satu komunitas yang menonjolkan rasa solidaritas yang tinggi adalah komunitas Vespa. Komunitas Vespa merupakan sekumpulan orang yang bergabung menjadi satu karena adanya kesamaan hobi, kegemaran mengkoleksi dan mengendarai kendaraan jenis motor antik produksi Italy yang disebut Scooter atau yang biasa disebut adalah Vespa. Berbeda dengan komunitas motor lain yang sangat menunjukan kemewahannya, di dalam komunitas vespa mereka tidak mengenal status sosial, tua, muda, pengangguran, penguasaha, pekerja bergabung menjadi satu, sehingga memiliki nilai kebersamaan yang dipandang sebagai status sosial yang sangat tinggi.

Berawal dari saling bertukar informasi diantara para penggemar vespa, hubungan ini kian erat dan akhirnya terjalin persaudaraan yang melahirkan komunitas yang tidak menonjolkan ego individu, namun hal ini lebih mengarah kepada persaudaraan antara sesama penggemar vespa, salah satunya adalah Scooter Mods Bogor Indonesia (combi). Combi terlahir pada tanggal 03 Maret 2011 di Kota Bogor. Combi terbentuk karena Sekumpulan orang yang memiliki rasa kecintaan terhadap Vespa. Combi memiliki kurang lebih 35 anggota yang terdaftar di dalamnya dan memiliki jadwal rutin untuk berkumpul bersama setiap Sabtu malam di depan Pengadilan Kota Bogor. Dengan mengutamakan rasa kekeluargaan dan solidaritas yang tinggi membuat Combi masih ada hingga sekarang.

Mencapai tujuan tersebut, maka diperlukan adanya keinginan yang kuat untuk melakukan suatu kegiatan yang membuat para anggota combi bisa mewujudkan tujuan yang diinginkan. Maka dari itu, kegiatan dari combi bukan hanya sekedar kumpul bersama, tetapi combi juga memiliki kegiatan untuk membangkitkan rasa solidaritas dan kekeluargaan itu sendiri. Kegiatan tersebut antara lain kegiatan internal berupa doa bersama setiap bulan guna untuk selalu diberikan perlindungan oleh Yang Maha Kuasa, lalu bakti sosial yang dilakukan setiap tahun untuk menumbuhkan rasa peduli dan berbagi antar sesama dan acara Touring atau perjalanan bersama ke suatu tempat guna untuk menjaga rasa kekeluargaan di antara anggota combi. Tidak hanya kegiatan internal, combi juga memiliki kegiatan eksternal yaitu perayaan hari jadi combi dan buka bersama pada bulan puasa. Kedua kegiatan tersebut tidak hanya diikuti 
oleh anggota combi saja, melainkan dengan mengundang anak yatim serta komunitas lain. Hal ini ditujukan agar menjaga hubungan baik antar sesama komunitas serta menjalin silaturahmi dengan masyarakat dalam hal ini para anak yatim.

Tidak hanya dengan melakukan suatu kegiatan untuk mencapai rasa solidaritas yang tinggi antar sesama anggota combi, namun perlu adanya rasa kesadaran dari setiap anggota. Hal itu memang harus dimiliki. Jika tingkat kesadaran anggotanya kurang, maka tidak akan terjalin rasa solidaritas yang diinginkan. Tentu saja tujuan yang hendak dicapai tidak akan terwujud karena kurangnya hal tersebut. Hasil obeservasi peneliti bahwa komunitas Scooter Mods Bogor Indonesia sendiri memiliki 35 anggota, 3 anggota diantaranya bekerja di luar kota dan 2 orang merupkan perempuan. Namun untuk menjembatani infromasi dalam program yang dilakukan, komunitas Combi memiliki beberapa jaringan sosial yaitu salah satunya Grup Whatsapp Massager (WA). Dalam jaringan sosial terdapat suatu gejala yaitu kurangnya respon yang dilakukan anggota melalui Grup WA yang berdampak kurangnya kehadiran dalam pertemuan yang dilakukan setiap sabtu malam. Kondisi ini terlihat pada sabtu malam tanggal 9 Juni 2017 pada saat membicarakan program tahunan yaitu "Buka Bersama oleh anak yatim.". Pada pertemuan tersebut terlihat hanya 15 orang yang hadir, dan yang tidak hadir diantaranya memiliki alasan yang beragam dan sisanya tidak ada informasi yang jelas. Padahal 4 hari sebelumnya sudah disebarluaskan informasi terhadap anggota untuk diwajibkan menghadiri pertemuan sabtu malam. Idealnya setiap pertemuan sabtu malam diharapkan kehadiran seluruh anggotanya untuk memberikan sumbangsih baik secara fisik maupun pikiran untuk terlaksananya suatu program rutinitas. Dari gejala tersebut menunjukan kurangnya kesadaran terhadap setiap anggota dalam mersepon informasi. Hal tersebut membuat sulitnya mencapai tujuan yang harapkan.

Riwayadi dan Anisyah (2005) dalam Kamus Besar Bahasa Indonesia menyatakan bahwa Solidaritas adalah sifat perasaan setia kawan. Namun ada juga teori yang menjelaskan tentang solidaritas, (Lawang 1985) bahwa solidaritas sosial adalah keadaan saling percaya antar anggota kelompok atau komunitas. Jika saling percaya akan menjadi satu atau menjadi sahabat, saling menghormati, saling bertanggung jawab untuk saling membantu dalam memenuhi kebutuhan antar sesama. Namun ada juga yang menjelaskan Solidaritas sosial menurut (Johnson 1980) bahwa solidaritas menunjukkan pada suatu keadaan antar individu dan atau kelompok yang didasarkan perasaan moral dan kepercayaan yang dianut bersama, yang diperkuat oleh pengalaman emosional bersama. Kutipan diatas dapat disimpulkan bahwa solidaritas itu bisa terjalin jika ada pengalaman emosional dan kepentingan moral yang dialami secara bersama antar anggota suatu komunitas. Dengan kata lain, solidaritas seseorang dalam mencapai tujuan bersama ditandai dengan adanya pengalaman emosional dan kepentingan moral secara bersama pada setiap anggota untuk mencapai tujuan bersama yang telah disepakati. Jika dikaitkan dengan tujuan Combi adalah mencapai tujuan bersama secara internal dan eksternal yang telah diterapkan organisasi Combi.

Pada upaya untuk menumbuhkan kesadaran seseorang, (Ritonga 2005) mengatakan bahwa komunikasi persuasif merupakan usaha sadar untuk mengubah pikiran dan tindakan dengan memanipulasi motif-motif ke arah tujuan yang telah ditetapkan. Makna memanipulasi disini bukan mengurangi atau menambah fakta sesuai konteksnya, dalam arti lain yaitu mencoba merubah mindset atau pemikiran seseorang. Secara sederhana, melalui pendekatan ini kita melakukan proses komunikasi untuk menyadarkan setiap anggota yang kurang memiliki kesadaran 
dalam menumbuhkan rasa solidaritas. Kutipan diatas, jika dikaitkan dengan sbujek penelitian bahwa komunikasi persuasif memiliki kekuatan untuk menyadarkan anggota pada tujuan organisasi.

Proses komunikasi yang dimaksudkan dalam guna menyadarkan anggota Combi ke arah kepentingan bersama atau untuk mencapai pengalaman emosional dan keputusan moral, yaitu melalui pendekatan jaringan komunikasi WA. Adapun tujuan penelitian ini adalah (1) Mengetahui komunikasi persuasif dalam mencapai kesadaran anggota Scooter Mods Bogor Indonesia. (2) Mengetahui bagaimana solidaritas di Scooter Mods Bogor Indonesia. (3) Mengetahui apakah ada pengaruh antar komunikasi persuasif terhadap solidaritas anggota Scooter Moods Bogor Indonesia mecapai tujuan.

\section{METODE PENELITIAN}

\section{Pendeketan Penelitian}

Penelitian ini menggunakan pendekatan kuantitatif. Menurut Sugiyono (2009a) metode kuantitatif dapat diartikan sebagai metode penelitian yang bersifat postpostivisme, yang digunakan untuk meneliti pada populasi atau sampel tertentu, pengumpulan data menggunakan instrumen penelitian, analisis data bersifat statistik dengan tujuan untuk menguji hipotesis yang telah ditetapkan.

\section{Teknik Penelitian}

Penulis menggunakan metode penelitian deskriptif dan asosiatif, yaitu penelitian yang diolah dan dianalisis untuk diambil kesimpulan. Metode deskriptif diartikan sebagai suatu prosedur pemecahan masalah yang diselidiki dengan menggambarkan keadaan subjek atau objek penelitian yang terjadi pada saat sekarang berdasarkan fakta-fakta yang terlihat dilapangan sebagaimana mestinya (Hadari 2001). Sedangkan metode Asosiatif, yaitu metode yang digunakan untuk menjelaskan tentang adakah korelasi antara komunikasi persuasif untuk kesadaran dan solidaritas anggota Scooter Moods Bogor Indonesia. Menurut Sugiyono (2013b) yang dimaksud penelitian Asosiatif adalah "Penelitian yang bertujuan untuk mengetahui hubungan antara dua variabel atau lebih, dengan penelitian ini maka akan dapat dibangun suatu teori yang dapat berfungsi untuk menjelaskan, meramalkan, dan mengontrol suatu gejala".

Peneliti menggunakan dua variabel yaitu satu variabel independen (variabel bebas) yaitu variabel yang mempengaruhi atau yang menjadi sebab perubahannya atau timbulnya variabel dependen dan satu variabel dependen (terikat) yaitu variabel yang dipengaruhi atau yang menjadi akibat, karena adanya variabel bebas (Sugiyono 2013b). Adapun variabel bebas dalam penelitian ini adalah komunikasi persuasif untuk kesadaran (X) sedangkan variabel terikat dalam penelitian ini adalah solidaritas anggota Scooter Moods Bogor Indonesia (Y). Sedangkan korelasi yang akan digunakan dalam penelitian ini adalah Korelasi Rank Spearman yaitu korelasi yang digunakan untuk mencari signifikan hipotesis asosiatif bila masing-masing variabel yang dihubungkan berbentuk ordinal dan sumber data antar variabel tidak harus sama.

Sampel, peneliti menggunakan teknik sampling jenuh. Sugiyono (2013b), "Sampling jenuh adalah teknik penentu sampel apabila semua anggota populasi dipergunakan sebagai sampel". Penelitian ini memakai teknik sampling jenuh karena jumlah populasi yang ada terjangkau oleh peneliti yaitu sebanyak 35 orang, yang terdistribusi hanya di satu komunitas saja. sampling jenuh ini juga dinamakan sensus sampling, karena semua anggota populasi dipakai sebagai sampel peneliti. Berdasarkan teknik sampel yang telah dipilih oleh peneliti yaitu sampel jenuh (sensus sampling), maka sampel peneliti berjumlah 35 orang. 
Teknik Pengumpulan dan Pengolahan Data

Pertama teknik pengumpulan data dengan studi kepustakaan berkaitan dengan kajian teoritis dan referensi lain yang berkaitan dengan nilai, budaya dan norma yang berkembang pada situasi sosial yang diteliti. Kedua studi Lapangan, pengumpulan data dengan meninjau secara langsung ketempat lokasi penelitian, penulis melakukan ini untuk mendapatkan data dan informasi yang berhubungan dengan permasalahan yang dibahas dalam penelitian ini dengan cara observasi, wawancara dan kuesioner. Data ditabulasikan dan diinterpretasikan dan di bahas dengan menggunakan pendekatan kualitatif.

\section{HASIL DAN PEMBAHASAN}

\section{Komunikasi Persuasif Dalam Mencapai Kesadaran Anggota Scooter Mods Bogor Indonesia}

Ritonga (2005) pesan persuasif dipandang usaha sadar untuk mengubah pikiran dan tindakan memanipulasi motif-motif ke arah tujuan yang telah ditetapkan. Upaya mempengaruhi orang lain, seseorang cenderung memberikan perhatian khusus tentang bagaimana orang lain menilai dirinya, sehingga orang tersebut dapat menyesuaikan diri dengan bentuk partisipasi yang sesuai untuk dilakukan, dan kemudian secara perlahan akan mempengaruhi penilaian orang lain terhadap dirinya dalam lingkungan sosial tersebut.

Tabel. 1 Kriteria Kesadaran Anggota Scooter Mods Bogor Indonsia

\begin{tabular}{clcc}
\hline No & Instrumen & Rarata & Kriteria \\
\hline $\mathbf{1}$ & Pesan Persuasif & 4,33 & Sangat baik \\
$\mathbf{2}$ & Solidaritas & 4,52 & Sangat Baik \\
& Total & $\mathbf{4 , 4 2}$ & Sangat Baik \\
\hline
\end{tabular}

Sumber : Data Olahan 2017

Berdasarkan Hasil penelitian di dapatkan hasil perhitungan variabel komunikasi persuasif sebesar 4,33 dengan kategori sangat baik. dengan demikian dapat kita lihat bahwa komunikasi persuasif dalam komunitas Combi sudah sangat baik. dan diperkuat oleh hasil rekapitulasi dimensi tidak terdapat unsur memaksa yang memperoleh angka penafsiran sebesar 4.22 dengan kriteria baik.

Hal ini diperkuat oleh Rahmawan (2014) komunikasi persuasif aktifitas komunikasi yang bertujuan untuk menciptakan perubahan pengetahuan, sikap, mental, dan perilaku khalayak sasaran terhadap ide pembaharuan ditawarkan.

Peran komunikasi persuasif terhadap anggota Scooter Mods Bogor Indonesia adalah memberikan informasi kepada anggota terhadap informasi berkenaan dengan kegiatan anggota, selain itu menjalin silahturami yang lebih erat sesama anggota. Nuryanto (2014) komunikasi persuasif mampu memberikan kedekatan antar anggota melalui pembentukan solidaritas yang kuat dengan intensitas komunikasi yang rutin dalam bentuk tolong menolong dalam kehidupan sehari hari. 


\section{Solidaritas Scooter Mods Bogor Indonesia}

Johnson (1980) solidaritas menunjukan pada suatau keadaan dalam rekapitulasi antar individu atau kelompok yang di dasarkan perasaan moral dan kepercayaan yang dianut bersama, yang diperkuat oleh pengalaman emosional bersama.

Pada penelitian ini mendefinisikan solidaritas Scooter Mods Bogor Indonesia adalah terbentuknya sebuah kekeluargaan yang didasari dengan silahturami yang erat. Pada variabel solidarias, menunjukkan nilai sebesar 4.52. Hal ini memiliki makna bahwa solidaritas yang terbentuk dengan sangat baik.

Taryanto (2012) solidaritas terbentuk karena rasa persahabatan yang kuat antara anggota komunitas, dengan adanya solidaritas dalam komunitas maka semakin kompak sehingga dapat mengisi kekurangan satu dan lainnya. Dengan terbentuknya solidaritas maka mereka akan merasa nyaman dan senang berada dalam komunitas. Perasaan senang dan nyaman dalam komunitas menimbulkan kesan positif pada setiap anggotanya sehingga mereka dapat berinteraksi dan melakukan kegiatan dengan baik.
Penelitian ini sejalan dengan temuan dari Taryanto (2012) Komunitas Vespa di Indonesia terkenal dengan solidaritas yang kuat, moto satu Vespa sejuta saudara"yang sangat mendalam bagi setiap komunitas Vespa. Hal ini terlihat pada setiap kegiatan di komunitas Scooter Mods Bogor Indonesia.

Solidaritas mampu memberikan kesadaran kolektif yang kuat melalui interaksi sosial dengan membangun nilanilai kekeluargaan serta kesadaran bagi anggota. Hal ini tampak pada komunitas vespa memperlihatkan kegiatan antara lain buka bersama dengan anak yatim, anniversary ulang tahun komunitas, dan touring bersama. Kegiatan tersebut menjadi interaksi sosial yang membentuk solidaritas organik.

\section{Pengaruh Komunikasi Persuasif Terhadap Solidaritas Anggota Scooter Moods Bogor Indonesia Mecapai Tujuan}

Pengajuan hipotesis penelitian ini adalah terdapat pengaruh antara komunikasi persuasif terhadap solidaritas anggota Scooter Moods Bogor Indonesia. Hasil uji SPSS 16 dari olahan data menunjukkanpada Tabel 2.

Tabel. 2 Pengaruh Komunikasi komunikasi persuasif terhadap solidaritas anggota Scooter Moods (Spearman's test)

\begin{tabular}{ccc}
\hline Pengaruh & \multicolumn{2}{c}{ Nilai } \\
\cline { 2 - 3 } & Sig (2-tailed) & Koofisen Korelasi \\
Pesan Persuasif & 0,000 & $0,646^{* *}$
\end{tabular}

Keterangan : **Signifikansi pada $99 \%$

Berdasarkan hasil tersebut dapat dilihat bahwa jumlah data penelitian $(\mathrm{N})$ adalah sebanyak 35 responden, dapat dasumsikan bahwa ada hubungan yang signifikan antara komunikasi persuasif dan solidaritas. Selanjutnya, dari output di atas diketahui nilai korelasi antara variable persuasif dengan solidaritas adalah sebesar 0,646. Jika berdasarkan tabel interpretasi koefisien terkategori kuat.

Menjawab hipotesa penelitian ini maka didapat $\mathrm{t}$ hitung $=6,363$ dan $\mathrm{t}$ tabel $=2,035$. Dengan demikian (thit> ttabel) dimana $\mathrm{Ha}$ diterima dan Ho ditolak, berarti 
komunikasi persuasif (X) berpengaruh nyata dan positif terhadap solidaritas (Y).

Adapun koofisien determinasi (Kd) yang didapat adalah 41,73\%. Perhitungan tersebut dapat dimaknai bahwa komunikasi persuasif mempengaruhi solidaritas sebesar 41,73\%, dan 58,27 \% dipengaruhi oleh factor sosial lainnya. Nuryanto (2014) interaksi mampu menciptakan solidaritas yang di dorong oleh komunikasi yang persuasif dimana ditunjukan dengan adanya pertemuan, kegiatan, serta pemecahan masalah bersama.

\section{KESIMPULAN DAN IMPLEMENTASI}

\section{Kesimpulan}

1. Komunikasi persuasif sebesar 4,33 dengan kategori sangat baik. dimana komunikasi persuasif dalam komunitas Combi sudah sangat baik terbukti dengan tidak adanya unsur paksaan

2. Solidaritas di komunitas Scooter Mods Bogor Indonesia mendapatkan nilai 4.52 dengan kategori sangat baik. Hal ini menunjukan bahwa solidaritas di Scooter Mods Bogor Indonesia sudah sangat baik.

3. Komunikasi persuasif berpengaruh terhadap solidaritas dengan nilai 4,33 dengan kategori Sangat Baik. adapun solidaritas menghasilkan nilai 4,52 dengan kategori Sangat Baik. Dimana Ha diterima. Dengan Tingkat kontribusi determinasi sebesar $41,73 \%$.

\section{Implementasi}

1. Komunikasi persuasif perlu ditingkatkan melalui dimensi dalam informasi yang seragam sesama anggota.

2. Solidaritas perlu ditingkatkan dengan sesama anggota Scooter Mods Bogor Indonesia dengan menciptakan media viral yang berbasis web. Sehingga mampu membangun nilai transparansi bersama anggota dan kelompok.
Perilaku anak yang dimati dalam penelitian ini adalah kognitif, afektif dan behavioral. Adapun aspek kognitif adalah pengetahuan dan pemahaman. Aspek afektif adalah perasaan setalah menonton sinetron Anak Jalanan. Sedangkan pada aspek behavioral adalah tindakan dan perilaku setelah menonton sinteron tersebut. Adapun hasil penilaian yang ditanyakan kepada anak-anak menunjukkan hasil yang tertera pada Tabel 2. Perilaku anak setelag menonton tayangan Sinetron Anak Jalanan.

\section{DAFTAR PUSTAKA}

Hadari N. 2001. Penelitian Terapan. Yogyakarta (ID) : Gajah Mada Uiversity Press.

Johnson DP. 1986. Teori Sosiologi Klasik dan Modern Jilid I. Jakarta (ID): PT Gramedia.

Lawang RMZ. 1985. Pengantar Sosiologi. Jakarta (ID): Karunika.

Nuryanto MRB. 2014. Studi Tentang Solidaritas Sosial Di Desa Modang Kecamatan Kuaro Kabupaten Paser (Kasus Kelompok Buruh Bongkar Muatan). eJournal Konsentrasi Sosiologi; 2 (3):53-63.

Rahmawan SH. 2014. Pengaruh Komunikasi Persuasif Terhadap kesadaran Pajak Pedagang Di Pasar Rangkas Bitung [Skripsi]. Banten (ID): Universitas Sultan Ageng Tirtyasa.

Ritonga MJ. 2005. Tipologi Pesan Persuasif. Jakarta (ID): Indeks.

Riwayadi S dan Suci NA. Kamus Lengkap Bahasa Indonesia. Surabaya (ID): Sinar Terang. 
Sugiyono. 2009a. Metode Penelitian Kuantitatif, Kualitatif dan R\&D. Bandung (ID). Alfabeta.

Sugiyono. 2013b. Metode Penelitian Sosial. Bandung (ID). Alfabeta.

Taryanto HS. 2012 Satu Vespa Sejuta Saudara: Nilai-Nilai, Solidaritas, dan Kreativitas Komunitas Vespa Apa Aja Boleh dalam Menciptakan Vespa Ekstrim [Skripsi]. Depok. (ID) : Universitas Indonesia.

Wenger E, McDermott R. Snyder W. 2002. Cultivating Communities of Practice. Massachusetts (USA). Harvard Business School Press. 